\title{
Transgresión lógica y semántica en la literatura fantástica contemporánea: análisis de unos relatos de Julio Cortázar a la luz de la bi-lógica de Ignacio Matte Blanco
}

\author{
Giuliana ZEPPEGNO \\ Universidad Complutense de Madrid
}

Todo lleva a creer que existe cierto punto del espíritu desde el cual la vida y la muerte, lo real y lo imaginario, el pasado y el futuro, lo comunicable y lo incomunicable, lo alto y lo bajo dejan de ser percibidos contradictoriamente.

André Breton, Segundo Manifiesto

Surrealista

Esto lo estoy tocando mañana.

Julio Cortázar, El perseguidor

\section{RESUMEN}

El relato fantástico contemporáneo se diferencia del decimonónico por unas características peculiares que modifican esencialmente la lógica del género, proporcionándole un carácter transgresivo casi completamente desconocido por el fantástico clásico. Los relatos fantásticos más innovadores del siglo XX operan, por un lado, una transgresión semántica, en la medida en que se niegan a la significación y tienden a adoptar una retórica que podemos llamar de la oscuridad; por otro lado, la mayor parte de ellos está construida alrededor de una transgresión de tipo lógico, que arremete contra la lógica clásica, aristotélica, tal como la definen los principios de identidad, no-contradicción y tercero excluido y las nociones de tiempo, espacio, relación de causa-efecto. El presente artículo examina el aspecto lógico de la transgresión fantástica, aplicando las teorías del psicoanalista chileno Ignacio Matte-Blanco sobre la "bi-lógica" al análisis de unos relatos fantásticos de Julio Cortázar, particularmente representativos de las infracciones lógicas fundamentales, a saber: contravenciones al principio de identidad; infracciones temporales y 
espaciales; violaciones relativas a la relación entre la parte y el todo y las relaciones entre las partes; interferencias lógicas en la relación entre concreto y abstracto.

Palabras clave: relato fantástico; Julio Cortázar; transgresión; Ignacio Matte Blanco, Bilógica.

\begin{abstract}
The contemporary fantastic short story differs from the 19th century one because of some particular features, which essentially change the logic of the genre by giving it a transgressive nature which were almost unknown to the classic fantastic. On the one hand, the 20th century most innovative fantastic short stories commit a semantic transgression, as far as they refuse the transmission of meaning and adopt what we can call a rhetoric of obscurity; on the other hand, most of them are built around a logical transgression, which attacks the classical, aristotelian logic, such as it is defined by the principles of identity, noncontradiction, and excluded middle, and by the notions of time, space and cause-effect relation. This article examines the logical aspect of the fantastic transgression, by applying the chilean psychoanalyst Matte Blanco's theory on "Bi-logic" to the analysis of some Julio Cortázar's fantastic short stories, which are particularly emblematic of the most important types of transgression, namely: infringements of the principle of identity; temporal and spatial transgressions; violations of the relationship between the part and the whole and between the parts; logical interferences in the relationship between the concrete and the abstract.
\end{abstract}

Keywords: fantastic short story; Julio Cortázar; transgression; Ignacio Matte Blanco, Bilogic.

A pesar de las amplias divergencias existentes sobre la definición de lo fantástico y su deslinde temporal, los críticos coinciden en reconocer, como conditio sine qua non del género, la problematización y puesta en crisis del concepto de real y de la noción, que de ello deriva, de posible ${ }^{l}$. Un relato norealista que carezca de semejante infracción del "paradigma de realidad"2 (porque describe un mundo maravilloso radicalmente distinto del nuestro, o encarna una

\footnotetext{
1 "Lo fantástico manifiesta un escándalo, una laceración, una irrupción insólita, casi insoportable en el mundo de la realidad [...] por tanto es ruptura del orden reconocido, irrupción de lo inadmisible en la inalterable legalidad cotidiana". R. Caillois (2004), pp. 150-152, trad. mía.

${ }^{2}$ Se adopta aquí la noción propuesta por Lugnani en L. Lugnani (1983). El concepto de "paradigma de realidad" resulta preferible al de "realidad" para describir el desvío producido por el agente fantástico, ya que hace resaltar el carácter convencional de lo que una cultura dada tiende a considerar como "norma", destacando así la peculiar historicidad del género fantástico, y por consiguiente su tendencia a "envejecer" o "deteriorarse" según la mutación de los códigos culturales.
} 
alegoría, o brinda una explicación psicológica, religiosa, pseudo-científica, etc. del acontecimiento imposible) sin duda es contiguo al fantástico pero no forma parte del género.

Mientras que el fantástico ha representado, a lo largo del siglo XIX, un género literario bien definido, homogeneizado por unas constantes tanto temáticas como formales, la literatura fantástica contemporánea (valga como línea de demarcación la narrativa kafkiana) constituye una realidad mucho más heterogénea, caracterizada por una tendencia casi constitutiva a la hibridación: de aquí que nos parezca oportuno hablar, para designarla, de una "modalidad" fantástica o, más simplemente, de lo fantástico. Este supergénero está compuesto por un amplio abanico de textos, diferenciados entre sí esencialmente por el tipo de relación que mantienen con la tradición del género y el diverso efecto que producen en el lector: relatos fantásticos canónicos, que reiteran los mismos dispositivos del fantástico à la Hoffmann; textos híbridos, de difícil colocación de género, en vilo entre modalidades representativas contiguas, como lo maravilloso, lo surreal, lo prospectivo $^{3}$ (el mismo Kafka, a menudo expeditivamente incluido en el género fantástico, es autor de muchas narraciones de este tipo); relatos irónicos y paródicos, que juegan con las estructuras y los tópicos del género fantástico y gótico; relatos en la frontera entre escritura ficcional y ensayística, que hacen brotar lo fantástico de la traducción diegética de hipótesis filosóficas o teológicas ${ }^{4}$; por último, cuentos fantásticos fuertemente innovadores con respecto a la tradición en la que se insertan ${ }^{5}$.

Esta última categoría se diferencia del relato fantástico clásico (decimonónico como contemporáneo) por unas características peculiares que modifican esencialmente la lógica estructural del género, proporcionándole un carácter transgresivo casi completamente desconocido por el relato fantástico anterior ${ }^{6}$. Ya

${ }^{3}$ La noción de género prospectivo ha sido propuesta por Fernando Ángel Moreno para dar cuenta de aquellas obras así llamadas de "ciencia ficción" que están basadas, en vez que en un simple adelanto científico dirigido a provocar el asombro del lector, en una prospección (exploración de posibilidades futuras) articulada de tal manera de desencadenar un conflicto cognitivo que anime al lector a la observación crítica y al replanteamiento de cuestiones socio-culturales. Cfr. F. Á. Moreno Serrano (2010).

${ }^{4}$ Piénsese en particular en la obra ficcional de Jorge Luis Borges y Adolfo Bioy Casares, maestros indiscutidos de lo que podríamos llamar lo fantástico "intelectual".

5 Estos cuentos constituyen, junto a los relatos fantásticos "epigonales" mencionados al principio de esta lista, un género fantástico bien reconocible dentro de la más amplia modalidad fantástica aquí sintéticamente descrita.

${ }^{6}$ Rosalba Campra, autora del libro más lúcido que se ha escrito recientemente sobre el género, considera el relato fantástico como un tipo de texto narrativo "que encuentra su dinamismo organizativo en la isotopía de la transgresión” (R. Campra, 2008, p. 193): "pienso que es posible decir que no existe texto al que le apliquemos la etiqueta «fantástico» que no presente una transgresión de lo dado como «natural»: sea a nivel semántico - como 
que el término transgresión, y aún más la palabra subversión y sus simétricos imperfectos conservación y regresión $\square$ no designan en absoluto un concepto transparente y unívoco, sino que se prestan a cierta confusión y simplificación, antes de abordar los textos es preciso aclarar qué se entiende, en este contexto, por transgresión, y matizar el término por medio de una adjetivación lo más rigurosa posible.

Al contrario de lo que puede parecer a primera vista, la literatura fantástica del siglo XIX manifiesta por lo general una tendencia conservadora con respecto al paradigma de realidad vigente: nacido sobre los escombros de la fe en lo maravilloso, "en el momento en que nadie ya cree en la posibilidad del milagro", el género fantástico clásico reacciona al racionalismo ilustrado recuperando códigos culturales desusados y superados (fantasmas, brujería, mundo infernal, vampiros, magia, etc.), pero lo hace de una forma altamente ambigua. Por un lado, su uso de temas transgresivos, como las diversas formas de la sexualidad en sus múltiples variantes y perversiones (incesto, necrofilia, homosexualidad, sadismo, vampirismo), a menudo acaba por actuar de manera funcional al orden constituido, proporcionando una satisfacción sustitutiva de deseos expulsados de la cultura, esto es, permitiendo una descarga provisional e inocua que acaba por neutralizar su potencial subversivo. Por otro lado, la condescendencia del relato fantástico hacia códigos de lectura del mundo obsoletos, en un primer momento interpretable como una instancia contestataria, si bien regresiva, respecto al paradigma vigente, se revela una manera de "domesticar lo diferente" más que una verdadera relativización de la norma: lo superado que vuelve a aflorar en los relatos fantásticos clásicos, encerrado entre los paréntesis de la ficción narrativa y sometido a una función esencialmente lúdica, es destituido de su valor gnoseológico y no constituye ninguna amenaza para el sistema del saber: "perturbador" y "siniestro" (unheimlich) a nivel inconsciente pero inofensivo para la razón, lo reprimido vuelve, con carácter literario, más como demora nostálgica que como auténtico "replanteo" de la cultura.

superación de barreras entre dos órdenes de la realidad; sea en el nivel sintáctico - como desfase o carencia de funciones en sentido amplio; sea a nivel verbal - como negación de la arbitrariedad del signo y por ende como acción del significante sobre el significado." (p. 192). La estudiosa sin embargo, aunque destaque el cambio, a partir de la segunda mitad del siglo XX, de un tipo de fantástico "temático" a uno "discursivo", considera la transgresión como una prerrogativa de lo fantástico desde sus orígenes. La tesis que se desarrollará en las páginas siguientes, en cambio, es que sólo la literatura fantástica contemporánea puede considerarse, en sus manifestaciones más logradas, auténticamente transgresiva, mientras que gran parte del género fantástico clásico (decimonónico o sucesivo) encubre, debajo de una aparente transgresividad lógica y temática, instancias esencialmente conservadoras con respecto al paradigma dominante.

${ }^{7}$ R. Caillois (1985), p. 21, trad. mía. 
El relato fantástico más innovador del siglo $\mathrm{XX}$ alberga, por el contrario, una transgresión radical, exenta de cualquier ambivalencia hacia códigos culturales anteriores, por la sencilla razón de que pone en tela de juicio el paradigma de realidad dominante sin proponer ningún código alternativo. Los objetos o acontecimientos fantásticos que él convoca son creaciones ex novo: no existe, ni probablemente existirá nunca, un código en base al cual traducirlas. Si el objeto fantástico clásico hacía referencia a un saber enciclopédico asimilado desde generaciones, los monstrua de la literatura fantástica contemporánea ya no remiten a nada: formas desconocidas por el imaginario cultural y literario, y únicos elementos aberrantes en un mundo posible por lo demás perfectamente ajustado a las normas de lo real, abren brechas y vacíos en el paradigma de realidad, negándose a cualquier atribución "positiva" de sentido en el sistema textual al que pertenecen.

La transgresión que opera en este tipo de fantástico es por lo tanto, en primera instancia, una transgresión semántica, a saber, el rechazo de la significación y la consiguiente infracción del pacto de ficción tácitamente estipulado con el lector. En efecto, si el cuento fantástico clásico se valía preferentemente de una lógica de la ambigüedad, el contemporáneo estriba en una retórica que podríamos definir "de la oscuridad": mientras que el relato fantástico clásico tendía a producir una gama limitada de interpretaciones posibles, induciendo al lector a vacilar entre dos, máximo tres explicaciones del acontecimiento fantástico (según el esquema "o el fantasma existe $o$ bien el narrador está loco/borracho/ha soñado" etc.), el contemporáneo no abre ninguna posibilidad de interpretación, y lleva al lector a un impasse sin salida, "un absoluto punto muerto, un insuperable agarrotamiento del

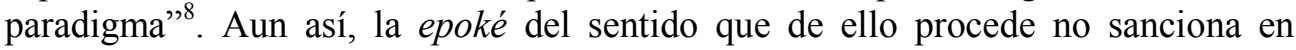
absoluto la renuncia a la interpretación: la imagen en torno a la cual se estructura el relato está vacía de un vacío lleno de sentido, densa de significados múltiples que no se anulan recíprocamente, y la oscuridad constitutiva del texto acaba por desembocar, en el plano metafórico y simbólico, en una polisemia afín a la que caracteriza la enunciación poética.

El examen de los relatos más significativos del género demuestra que dicha transgresión semántica es atribuible esencialmente a tres factores, o mejor dicho, a una determinada intersección entre tres elementos, ninguno de los cuales vale, él solo, para instituirla: 1) cierta novedad temática de la imagen fantástica contemporánea, intraducible a la luz de las enciclopedias dominantes y no reconducible a los códigos válidos para la narrativa fantástica tradicional; 2) el realismo y la verosimilitud del mundo representado, en ausencia de los cuales la transgresión carece de un blanco contra el que dirigir sus asaltos; y el carácter contradictorio del mundo ficcional instituido por el texto, que hace que la semántica

${ }^{8}$ L. Lugnani (1983), p. 72, trad. mía. 
de los mundos posibles resulte esencialmente insuficiente a la hora de analizarlo'; 3) un empleo sistemático de la reticencia narrativa, según las posibles variantes: $i$. de la reticencia explicativa (silencio en torno a las causas del acontecimiento fantástico, que es expuesto pero no explicado), $i i$. de la reticencia relativa a la fábula (se omiten enteros segmentos de la historia, a menudo el final, lo que produce las llamadas fábulas abierta ${ }^{10} s$ ), iii. de la reticencia semántica (silencio sobre el significado global, en sentido amplio simbólico, del relato) ${ }^{11}$.

Hasta aquí los rasgos generales, temático-formales, de la transgresión fantástica. Pero ¿cuál es, podría uno preguntarse ahora, la naturaleza específica de esta transgresión? ¿Qué leyes infringe?, ¿contra qué arremete?, ¿cuál es, en suma, el blanco privilegiado de sus asaltos? Las páginas siguientes esbozarán una respuesta a este interrogante, ilustrando el mecanismo de la transgresión fantástica mediante el análisis de algunos relatos de uno de los autores más emblemáticos de lo fantástico contemporáneo: Julio Cortázar.

\section{Lo simétrico}

Aunque se aprecian, en la literatura fantástica, muchas infracciones “ontológicas" de lo existente, es decir relatos en los que el escándalo tiene que ver más con la irrealidad de sus objetos que con su imposibilidad ${ }^{12}$, los cuentos fantásticos más interesantes sean probablemente los que entran directamente en colisión con la sintaxis del paradigma de realidad, a saber, con aquella armazón

\footnotetext{
${ }^{9}$ Para una profundización de la teoría de los mundos posibles, véase en particular: U. Eco (1999) у (2000); T. Pavel (1994); L. Doležel (1999). La teoría de los mundos posibles resulta extremadamente provechosa para el estudio de mundos ficcionales homogéneos (como los del relato realista o del cuento de hadas) u "homogéneamente híbridos" (como los relatos mitológicos), pero no logra dar cuenta de los mundos intrínsecamente contradictorios del relato fantástico, en el cual un solo elemento se encuentra en contradicción (lógica u "ontológica") con el mundo posible, por lo demás coherente y realista, que lo alberga.

${ }^{10}$ Véase en particular U. Eco (1999).

${ }^{11}$ A estas características hay que agregar la así llamada "naturalización de lo sobrenatural", técnica frecuente en el relato fantástico contemporáneo, consistente en referir el acontecimiento fantástico como natural, produciendo así el "extrañamiento" (Verfremdung) del lector y su consiguiente distanciamiento crítico de la realidad representada: si en el cuento fantástico tradicional el lector se asombraba junto al narrador o al protagonista, en el contemporáneo narrador y personajes relatan/viven la historia con absoluta naturalidad, y el único en percibir el escándalo es el lector.

12 Como ejemplo de transgresión "ontológica”, valga «Cefalea» (Bestiario, 1951) de Julio Cortázar: este relato presenta, además de una transgresión lógica radical, que se analizará al final de este artículo, una transgresión que podemos llamar "ontológica", en la medida en que alberga en su mundo posible un elemento "supernumerario", inexistente en el mundo real, es decir, una especie de misteriosos mamíferos denominados mancuspias.
} 
"invisible" (porque inherente al ser humano o porque interiorizada hasta el punto de no percibir ya su existencia) constituida por la lógica clásica, aristotélica, tal como la definen los principios de identidad, no-contradicción y tercero excluido y las nociones de tiempo, espacio, relación de causa-efecto.

La pregunta por el carácter innato o adquirido del logos, por la existencia de una lógica alternativa y la posibilidad de expresarla, ha atormentado a muchos pensadores a lo largo del siglo XX, llevándolos a la misma aporía: la imposibilidad de soslayar el logos para afirmar, fuera del logos, algo que por definición se le escapa. Comenta, al respecto, Gilles Deleuze:

Fueron siempre momentos extraordinarios aquellos en los que la filosofía hizo hablar el Sin-fondo y encontró el lenguaje místico de su furia, su informidad, su ceguera: Boehme, Schelling, Schopenhauer. En principio Nietzsche era uno de ellos, discípulo de Schopenhauer en El nacimiento de la Tragedia [...] Pero, aun con el riesgo de hacer hablar al fondo informe y el abismo indiferenciado, con toda su voz de ebriedad y de cólera, no se sale de la alternativa impuesta tanto por la filosofía trascendental como por la metafísica: fuera de la persona y del individuo, nada se distingue... ${ }^{13}$

En el intento de aproximarse a este innominable, que definir "ilógico" implica ya una concesión de primacía a la lógica y el síntoma de un (inevitable) logocentrismo, la filosofía ha recurrido a menudo a imágenes oscuras, en la frontera con la literatura: piénsese por ejemplo en la noción de "dionisíaco" de Nietzsche, en el Das Ding de Lacan, y sobre todo en los conceptos de "Sinrazón" y "pensamiento del afuera" $" 14$ propuestos por Michel Foucault, y en la crítica que a dicho planteamiento dirigió el discípulo herético Jacques Derrida ${ }^{15}$. Pero logos y lenguaje,

\footnotetext{
${ }^{13}$ G. Deleuze (2005), pp. 140-141.

${ }^{14}$ Véase M. Focuault (1991) y (1988).

15 Según Foucault, el progresivo "enmudecimiento" de la sinrazón (déraison), por el que ésa es privada del estatuto de sujeto y alienada a sí misma (es decir, reducida a puro objeto, a "ausencia de obra"), es un proceso histórico, cuyo inicio se puede hacer coincidir con la formulación del cogito cartesiano. Para Derrida, en cambio, la imposibilidad de la locura de ser sujeto de un discurso autónomo dependería de la estructura misma del pensamiento occidental, tal como se ha definido al menos a partir de la reflexión socrática. El cogito no decretaría en absoluto la expulsión de la locura del territorio del logos: por el contrario, la incluiría en un todo más amplio con respecto al cual ella vendría a representar, no el "afuera", sino un simple caso; un todo más amplio, comprensivo de razón y locura, que empero sería ya, forzosamente, un logos. El proyecto foucaultiano se estrellaría por lo tanto contra un límite intrínseco al pensamiento humano: la imposibilidad de soslayar la razón para dar voz a la locura en sí: la historia de la locura desde el punto de vista de la locura no es otra cosa, en palabras de Derrida, sino "la arqueología del silencio" (J. Derrida, 1989, p.
} 
como no se cansó nunca de repetir Cortázar, son el aire mismo que respiramos, la íntima sustancia que nos constituye: si fuera del logos no se ve nada, como afirma Deleuze, en su interior no se ve sino lo que el logos permite ver. El límite es inherente a la razón misma, que no puede pensar ni tanto menos expresar su "afuera" sino como negación del pensamiento, esto es, como enmudecimiento de cualquier lenguaje racional.

No obstante, lo que nos está cerrado en el plano del pensamiento quizá se abra a la creación estética, como demuestran poemas, relatos y novelas capaces de dar voz, en las formas del símbolo, de la metáfora fulminante, de la oscuridad y densidad semántica, a contenidos que por definición sobrepasan los límites de la ratio: en este sentido, el escándalo lógico que el relato fantástico contemporáneo injerta en el corazón de un mundo posible consecuente en todas sus partes puede considerarse una de las estratagemas con las que la ficción narrativa consigue sublevarse contra sus mismos instrumentos y sabotear, desde el interior, la lógica en la que estriba.

Entre los pensadores que en tiempos recientes se han enfrentado con este "reino de lo ilógico", destaca el psicoanalista chileno Ignacio Matte Blanco, para muchos pilar fundamental del surgimiento de la teoría psicoanalítica en Chile, cuyas teorías sobre la bi-lógica ${ }^{16}$, surgidas de la tentativa de traducir en términos lógicos la descripción freudiana del inconsciente, implican una verdadera revolución no sólo psicoanalítica sino también filosófica y epistemológica tout court. Es esta teoría a la que vamos a dirigirnos para investigar la transgresión fantástica contemporánea, convencidos de hallar en ella un adecuado marco de referencia y un útil instrumento para ilustrar y profundizar su naturaleza.

Matte Blanco empieza su reflexión partiendo de las características del sueño y más en general del sistema inconsciente que Freud enuncia respectivamente en $L a$ interpretación de los sueños (1899) y en El inconsciente (1915). En la primera, Freud reconduce la elaboración onírica a los procesos primarios de la condensación y del desplazamiento, y a unos medios de representación propios del inconsciente,

54), y su destino la opción entre una determinada forma del callar, por un lado, y el exilio del loco, por otro.

${ }^{16}$ La teoría de la bi-lógica, elaborada a partir de 1956 y desarrollada en diversos estudios sucesivos, llega a su sistematización en 1975, con el ensayo The Unconscious as Infinite Sets. An Essay in Bi-logic (El inconsciente como conjuntos infinitos. Ensayo sobre la bilógica). En 1988, Matte Blanco publica el segundo volumen de una ideal trilogía que sin embargo no llegará a completar: Thinking, Feeling and Being. Clinical Reflections on the Fundamental Antinomy of Human Beings and World (1988) (Pensar, sentir, ser. Reflexiones clínicas sobre la antinomia fundamental de los seres humanos y el mundo). Además de varios trabajos científicos y clínicos, Matte Blanco redactó también unos escritos de estética, donde se esboza una aplicación de la bi-lógica al arte y la literatura. Véase en particular los ensayos, redactados en italiano, I. Matte Blanco (2000a) y (2004). 
entre los cuales destacan: la co-presencia de contradictorios y ausencia de negación; la alternación entre ausencia y presencia de la sucesión temporal; la tendencia del sueño a reproducir el vínculo lógico como simultaneidad; su tendencia a reproducir el nexo causal como sucesión; la imposibilidad de representar las opciones alternativas como tales ("o...o"); la primacía de las relaciones analógicas; el simbolismo ${ }^{17}$. En El inconsciente, Freud retoma dichas características extendiéndolas a todos los procesos inconscientes, cuyo funcionamiento sintetiza del modo siguiente: "Resumiendo, diremos que los caracteres que esperamos encontrar en los procesos pertenecientes al sistema Inc. son la falta de contradicción, el proceso primario (movilidad de las cargas) [es decir: los procesos de condensación y desplazamiento, NdR], la independencia del tiempo y la sustitución de la realidad exterior por la psíquica"18.

El estudio de estos procesos y de los caracteres formales que de ellos dependen llevaría a Freud a realizar lo que él mismo definió como "el más válido de todos los

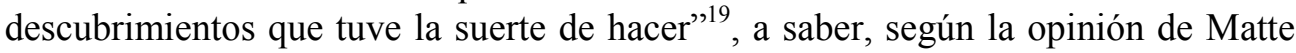
Blanco, no simplemente la existencia en la psique de un material inconsciente objeto de represión, ya presagiada por la psicología de la época, sino la intuición

[...] de un mundo "que él desafortunadamente llamó el inconsciente" gobernado por leyes completamente diferentes de las por las cuales es gobernado el pensamiento consciente. Él no fue el primero en hablar del inconsciente, sobre el cual ya mucho se sabía, pero fue el primero en hacer el descubrimiento fundamental de este extraño "reino de lo ilógico" sometido, a pesar de su ser ilógico, a leyes determinadas que descubrió con un excepcional golpe de genio ${ }^{20}$.

Según la lectura de Matte Blanco, el carácter inconsciente del "nuevo mundo" que Freud, como Colón, murió sin haber reconocido en su auténtica naturaleza, no sería el resultado de un proceso de represión, sino la necesaria consecuencia de sus rasgos peculiares:

[...] el origen de este problema reside en que lo que Freud en un primer momento describió con el nombre "el inconsciente" no era tan sólo una cualidad fino una forma de ser, caracterizada por otras muchas propiedades esenciales además de la de ser inconsciente. El ser inconsciente era una consecuencia necesaria de su

\footnotetext{
${ }^{17}$ S. Freud (2006), cap. VI.

${ }^{18}$ S. Freud (2006a), p. 2073.

${ }^{19}$ S. Freud, Prefacio a la edición inglesa The Interpretation of Dreams, p. 9, cit. en I. Matte Blanco (2000), p. 41. La traducción de la presente cita y de las sucesivas citas de la obra de Ignacio Matte Blanco son mías.

${ }^{20}$ I. Matte Blanco (2000), p. 105.
} 
estructura y de la estructura de aquella otra forma de ser, que Freud describió como "el consciente", pero ésta no era su única característica distintiva.

Las así llamadas características del sistema inconsciente son mucho más centrales a esta forma de ser que el hecho de ser inconsciente. Es por causa de éstas que esta forma de ser no puede entrar directamente en la conciencia: la conciencia no tiene las dimensiones para contenerla; asimismo, no se puede verter agua en una jarra pintada porque esta jarra sólo tiene dos dimensiones y para acoger el agua se necesitan tres ${ }^{21}$.

Esta peculiar "forma de ser", inconsciente por su no-homogeneidad con respecto a la conciencia, coincidiría según Matte Blanco con aquella noción de inconsciente no reprimido que, si bien nunca formulada de modo exhaustivo, aflora repetidas veces a lo largo de la reflexión freudiana. Es sobre todo en el marco del modelo tripartito, en efecto, donde emergería la idea de un inconsciente estructural, no producto de una represión, característico de aquella instancia psíquica que Freud denominó Es (ello).

Investigando los fenómenos observados en pacientes esquizofrénicos, Matte Blanco llega a formular los dos principios lógicos que regularían no sólo, como cree en un primer momento, las manifestaciones psíquicas patológicas, sino los procesos inconscientes de cada individuo. El primero es el principio de generalización, que hasta cierto punto puede considerarse coincidente con la normal facultad de abstracción:

El sistema inconsciente trata a una cosa individual (persona, objeto, concepto) como si fuese un miembro o elemento de un conjunto o una clase que contiene otros miembros; trata a esta clase como subclase de una clase más general y a esta clase más general como subclase o subconjunto de una clase aún más general y así sucesivamente ${ }^{22}$.

Mientras que este primer principio no excede la lógica clásica, sino, como veremos, en su radicalización y combinación con el segundo, este último (principio de simetría) constituye por contra "el más formidable desvío de la lógica en la que se ha fundado todo el pensamiento filosófico y científico de la humanidad"23.

El sistema inconsciente trata a la relación inversa de cualquier relación como si fuese idéntica a la relación. En otras palabras, trata a las relaciones asimétricas como si fuesen simétricas ${ }^{24}$.

${ }^{21}$ I. Matte Blanco (2000), pp. 79-80.

${ }^{22}$ I. Matte Blanco (2000), p. 43.

${ }^{23}$ I. Matte Blamco (2000), p. 44.

${ }^{24}$ Ibídem. 
En lógica, una relación es simétrica cuando su inverso es idéntico a la relación (por ej. la relación "Pedro es hermano de Juan" es idéntica a "Juan es hermano de Pedro"); es asimétrica cuando la relación y su inverso son incompatibles ("Pedro es padre de Juan" es incompatible con "Juan es padre de Pedro"; se dirá, en cambio: "Juan es hijo de Pedro"). Cuando actúa el principio de simetría, la relación asimétrica es tratada como si fuera simétrica, contraviniendo a una ley lógica fundamental. Se dará, por lo tanto: "Pedro es padre de Juan" = "Juan es padre de Pedro".

Las consecuencias más inmediatas de este principio son el desmantelamiento tout court de la idea de sucesión (a falta de relaciones asimétricas, cualquier ordenamiento serial resulta imposible) y la identidad entre la parte y el todo (A contiene $\mathrm{B}=\mathrm{B}$ contiene $\mathrm{A}$ ): de la primera deriva la disolución de las nociones de espacio y tiempo tal como estamos acostumbrados a concebirlas sobre la base de la lógica clásica (por el principio de simetría, en efecto: "A está antes de $\mathrm{B}=\mathrm{B}$ está antes de $\mathrm{A}$ " y "A está después de $\mathrm{B}=\mathrm{B}$ está después de A", así como "A está a la izquierda de B = B está a la izquierda de A" etc.); mientras que la segunda lleva a una versión por así decirlo intensificada del principio de generalización, concebible también, en este sentido, como un "corolario del principio de simetría"25. Si una madre forma parte del conjunto de las madres, también el conjunto de las madres formará parte de la madre: por lo tanto, cada madre resultará indistinguible de la clase de las madres y, consecuentemente, de todas las demás madres de la misma clase. En palabras de Matte Blanco, de la equivalencia de la parte con el todo se infiere que:

\begin{abstract}
Cuando se aplica el principio de simetría, todos los miembros de un conjunto o una clase son tratados como idénticos entre ellos e idénticos al conjunto o a la clase; pues son intercambiables tanto con respecto a la función preposicional que determina o define la clase, como respecto a todas las funciones preposicionales que permiten distinguirlos entre ellos y por medio de las cuales [...] es posible afirmar, en lógica aristotélica, que un determinado elemento de la clase no es idéntico a otro ${ }^{26}$.
\end{abstract}

Dos elementos unidos por el hecho de ser parte de la clase de las madres, pero distintos por otras muchas funciones no comunes (el ser más o menos altas, rubias, policías, cubanas, etc.), bajo la acción del principio de simetría son tratados como idénticos no sólo en relación con la función que comparten (como ocurre en un normal proceso de abstracción), sino bajo todos los aspectos.

${ }^{25}$ I Matte Blanco (2000), p. 343

${ }^{26}$ I. Matte Blanco (2000), p. 45. 
Para Matte Blanco, los dos principios de simetría y generalización proporcionan una explicación lógica coherente de todas las propiedades del inconsciente señaladas por Freud. Limitándonos a las cuatro fundamentales, de las que derivan todas las demás, se ha visto que la ausencia de espacio y tiempo es consecuencia inmediata del principio de simetría; el desplazamiento se aclara mediante la acción conjunta del primer principio y de la equivalencia entre la parte y el todo que procede del segundo, por lo cual se tiende a asimilar un objeto a la clase a la que pertenece y simultáneamente a considerarlo idéntico, y por tanto intercambiable, con respecto a cualquier otra parte de la misma clase; la condensación es posible en razón de la "intercambiabilidad" de los elementos de una misma clase (puesta la existencia del "todo en cada parte"), en combinación con la multidimensionalidad del espacio psíquico inconsciente, lo que posibilita que diversas partes puedan ocupar lo que es advertido, en la inevitable "traducción" en términos de espacio tridimensional que opera la psique, como el mismo lugar; la ausencia de contradicción reciproca -es decir, la negación del principio de no-contradicción, en el que estriba la entera armazón de la lógica clásica- procede del hecho de que dos expresiones mutuamente contradictorias (como por ejemplo: está vivo/está muerto) pueden ser tratadas, a ciertas profundidades de la psique, "como partes de un todo más general, partes que no se excluirían recíprocamente" ${ }^{27}$ : si se las considera en el interior de una clase más amplia, inclusiva de todas las posibilidades concernientes la vida, las dos expresiones vivo y muerto, "de acuerdo con el principio de simetría y como consecuencia del principio de generalización" $" 28$, resultan idénticas.

De esta última observación emerge claramente que la misma negación, en el sistema inconsciente, carece de sentido. La ausencia de la negación en la forma de ser del inconsciente, a la que Freud llega empíricamente, es demostrada por Matte Blanco por vía lógica: en el momento en que dos elementos vinculados por una relación de negación recíproca ( $p$ y no- $p$ ) son incluidos dentro de una clase más amplia y tratados como idénticos por efecto del principio de simetría y de la consiguiente equivalencia entre la parte y el todo, entre $p$ y no- $p$ ya no existe ninguna diferencia.

Desarrollando las intuiciones freudianas sobre la base de los dos principios, Matte Blanco llega a la conclusión de que la psique y lo real están gobernados por la interacción e incesante tensión entre dos lógicas radicalmente distintas: por un lado la lógica aristotélica, que él llama asimétrica, bivalente, heterogénea, fundada en el principio de no-contradicción y en el binarismo verdadero/falso; por otro la lógica simétrica, "confusiva", homogénea, que tiende a disolver toda diferencia entre los objetos y a unir lo que la lógica clásica se inclina a separar. Según esta

${ }^{27}$ I. Matte Blanco (2000), p. 50.

${ }^{28}$ I. Matte Blanco (2000), p. 53. 
hipótesis, existirían zonas del pensamiento y aspectos de la realidad en los que el tiempo y el espacio se desvanecen, el principio de no-contradicción pierde sentido, la idea misma de causa decae, la parte y el todo, el individuo y la clase llegan a fundirse; "lugares" en los que una madre es a la vez todas las madres, el yo se fusiona con todos los yoes y el sujeto se disuelve en el objeto, a su vez indistinguible de todos los demás objetos.

En la naturaleza, sin embargo, lo simétrico nunca se da en estado puro: "en medio de la estructura de la lógica simplemente bivalente o aristotélica el principio de simetría hace su aparición en ciertos puntos y, como un poderoso ácido, disuelve cualquier lógica al alcance de la mano [...] El resto de la estructura lógica, sin embargo, permanece intacto" $"$. Un hipotético estado simétrico puro coincidiría con un todo indiferenciado, infinito, a la vez máxima afirmación y negación de todas las cosas, cuya misma concepción llegaría con dificultad al umbral de la conciencia y necesitaría, para expresarse, de formulaciones paradójicas. La vida psíquica y la realidad constan, en cambio, de un continuum de formaciones en diverso grado bi-lógicas, constituido por todos los posibles casos de proporción entre simetría y asimetría: si algunas manifestaciones mentales son absoluta prerrogativa de la lógica bivalente (es el caso de muchos contenidos sometidos a represión, del pensamiento matemático, de los procesos de abstracción, de los instintos), otras resultan en cambio conmixtiones o alternaciones (nunca fusiones) entre las dos lógicas, y por consiguiente, presentan en su interior islas de desorden o misterio que la lógica clásica no consigue, ella sola, aclarar.

La estructura bi-lógica por excelencia es el inconsciente no reprimido, del que Matte Blanco proporciona un modelo descriptivo por estratos, de simetría creciente hacia abajo; otras formaciones bi-lógicas son el sueño, la emoción y la idea de infinito. El intrínseco carácter paradójico de la idea de infinito, que los Griegos reprimieron excluyendo a priori la noción de infinito actual, derivaría del intento de pensar de forma finita algo de por sí ajeno al pensamiento, como resulta patente en la definición de Dedekind: "un conjunto es infinito cuando y sólo cuando se lo puede poner en correspondencia biunívoca con una de sus partes propias" ${ }^{\prime 30}$. No es difícil vislumbrar, en dicha formulación, la traducción en términos de teoría de los conjuntos de la equipotencia entre la parte y el todo que Matte Blanco llega a postular sobre la base del principio de simetría. En el ámbito de la teoría bi-lógica, la idea de infinito puede considerarse, además de una aplicación paradigmática del principio de simetría, un modelo explicativo global: el poder disolvente de lo simétrico puede ser concebido, en efecto, como un proceso de infinitización de

${ }^{29}$ I. Matte Blanco (2000), p. 62.

${ }^{30}$ I. Matte Blanco (2000), p. 39. 
relaciones, espacios, lugares, y el entero sistema inconsciente como un verdadero abismo de "conjuntos infinitos".

Entre las formaciones bi-lógicas que componen la realidad y el pensamiento humano, Matte Blanco incluye también la creación artística, que en algunas de sus manifestaciones emplearía estructuras simétricas "vistiéndolas" de lógica bivalente para volverlas comprensibles y comunicadoras. Esto se aprecia claramente, como se ha dicho con anterioridad, en la lírica, pero permite explicar también unos mecanismos característicos de la narración en prosa: en particular, el relato fantástico contemporáneo puede ser concebido como una estructura asimétrica en la que se abra camino, penetrando a través de una brecha o laceración imprevista, una porción de realidad simétrica, y su dispositivo específico como la emersión inesperada, dentro de un mundo posible en todo y por todo conforme a la lógica clásica, de verdaderas "islas de simetría". Más específicamente, entre los diversos modelos bi-lógicos descritos por Matte Blanco sobre la base de la cantidad de simétrico presente en su interior y de la forma en que las dos lógicas se entrelazan recíprocamente, el relato fantástico puede ser asimilado a la estructura denominada alassi (alternación asimetría/simetría). Ésta se da "cuando, a lo largo de un proceso de razonamiento que respeta la lógica clásica, se introduce un anillo simétrico, es decir, una zona o anillo que respeta el PS (principio de simetría, NdR)"31: se trata de una de las estructuras bi-lógicas más comunes, detectables tanto en el razonamiento del sujeto "delirante" como, aunque en distinta medida, en el del sujeto común.

Antes de pasar al examen de algunas de las principales infracciones lógicas mediante las cuales el relato fantástico construye sus efectos, se impone una puntualización fundamental. Sostener que la transgresión de las leyes lógicas es una prerrogativa del relato fantástico contemporáneo es evidentemente erróneo: la literatura fantástica tradicional, sobre todo la tardo-decimonónica, ofrece casos notables de puesta en cuestión de los conceptos clave de la lógica aristotélica, en particular de la noción clásica de identidad ${ }^{32}$. El género fantástico tradicional está notoriamente atestado de autómatas vivientes, cuadros que cobran vida y estatuas que se enamoran, por no hablar de las múltiples transgresiones relativas a la oposición vivo/muerto, que representa quizá el ámbito temático más explotado (piénsese, por ejemplo, en la fortuna del tema del vampiro o del revenant, seres suspendidos por su naturaleza entre la vida y la muerte).

La violación lógica presente en estos relatos, sin embargo, opera por lo general de forma indirecta, por estar ya incluida dentro de un sistema de referencia

\footnotetext{
${ }^{31}$ I. Matte Blanco (1995), p. 55.

32 Entre otros muchos relatos destacan los clásicos «El sosias» (1846) de Dostoievski, «William Wilson» (1839) de E. A. Poe, «La Venus de Ille» (1837) de Prosper de Mérimée, «La muerte enamorada» (1836) de Gautier, y la novela Los elixires del diablo (1815-1816) de E. T. A. Hoffmann.
} 
codificado que, si bien superado por la cultura, sigue poseyendo para su público un elevado grado de familiaridad y puede ser "descifrado" con facilidad. Su representación, además, privilegia la carrera de la justificación explícita, o sea, tiende a proporcionar, del acontecimiento lógicamente imposible, el desencadenante, el instrumento, la causa. En otros términos: una cosa es la usurpación de una identidad ocasionada por un elixir o un bebedizo, otra es el imprevisto, mudo, agrietarse de la identidad de un sujeto sin ninguna razón "plausible"; una cosa es el salto temporal vehiculado por un hechizo, otra es un desgarramiento temporal falto de detonantes causales y hasta tal punto aberrante como para hacer pedazos en el acto la noción misma de tiempo lineal.

En las páginas siguientes se tratará de rastrear, en el corazón de algunos cuentos fantásticos paradigmáticos de estas dinámicas, las fórmulas mínimas de las infracciones que ellos albergan, diferenciándolas entre: contravención al principio de identidad y no-contradicción; infracciones temporales y espaciales; violaciones relativas a la relación entre la parte y el todo y las relaciones entre las partes; interferencias lógicas en la relación entre concreto y abstracto.

\section{1 "Je est un autre”: la identidad en jaque}

El tema o motivo que con más frecuencia ha encarnado la puesta en cuestión de la noción tradicional de identidad es el de la metamorfosis, extremadamente fértil desde la antigüedad y ampliamente explotado por lo fantástico clásico y contemporáneo $^{33}$. El género fantástico más reciente, sin embargo, ha producido relatos construidos en torno a "simetrizaciones" identitarias aún más profundas y desconcertantes, relatos donde la violación de los principios de identidad y nocontradicción resulta aún más radical que aquella implícita en las metamorfosis ocasionadas por un hechizo, un estado alterado de conciencia, un pacto con el diablo. Particularmente paradigmático de este elevado grado de transgresión es «Lejana» (Bestiario, 1951) de Julio Cortázar.

El relato coincide casi enteramente con el diario en el que la joven protagonista, Alina Reyes, toma nota de la progresiva obsesión de que cae víctima a partir del momento en que, ideando anagramas para vencer el insomnio, formula mentalmente la frase "Alina Reyes, es la reina y..."34. El anagrama tiene el efecto de generar en la joven la conciencia de otra sí misma (la lejana, la que no es la reina), que acaba subvirtiendo radicalmente su existencia diurna:

${ }^{33}$ Valgan como ejemplos clásicos los relatos fantásticos basados en historias de vampiros o licántropos y, en el siglo XX, la que podemos considerar el paradigma de las todas las metamorfosis literarias sucesivas: La metamorfosis de Kafka (1912).

${ }^{34}$ J. Cortázar (1982), p. 38. 
Tan hermoso, éste, porque abre un camino, porque no concluye. Porque la reina y...

No, horrible. Horrible porque abre camino a ésta que no es la reina, y que otra vez odio de noche. A esa que es Alina Reyes pero no la reina del anagrama ${ }^{35}$.

La lejana -la protagonista lo descubre enseguida, o lo inventa descubriéndolo ${ }^{36}$ - es una pobre mendiga de Budapest, a la que alguien pega a diario, y cuyos zapatos rotos dejan entrar la nieve: progresivamente invadida por la identidad de la lejana, Alina empieza a vivir en un "aquí" constantemente usurpado por un "en otra parte", por efecto de una duplicación de su conciencia que el lector no sabe si atribuir a la paranoia, al juego o a la realidad. En el diario, dicho desdoblamiento es descrito (y por lo tanto es realizado, en el relato) mediante una incongruente oscilación de los pronombres y algunas acrobacias narrativas:

Porque a mí, a la lejana, no la quieren. Es la parte que no quieren y cómo no me va a desgarrar por dentro sentir que me pegan o la nieve me entra por los zapatos cuando Luis María baila conmigo y su mano en la cintura me va subiendo como un calor a mediodía, un sabor a naranjas fuertes o tacuaras chicoteadas, y a ella le pegan y es imposible resistir y entonces tengo que decirle a Luis María que no estoy bien, que es la humedad, humedad entre esa nieve que no siento, que no siento y me está entrando por los zapatos ${ }^{37}$.

A pesar de su persistente incredulidad ${ }^{38}$, Alina se resuelve a buscar a su doble para acabar con la que percibe cada vez más como una usurpación, y convence al prometido a casarse y a llevarla a Budapest de viaje de novios. Con la boda se interrumpen las páginas del diario, pero no la historia, que sigue relatada por un narrador externo, en pasado y en tercera persona. Es por medio de este fragmento de narración "objetiva" como nos enteramos de que Alina, alcanzado el puente del Danubio, donde "la harapienta mujer de pelo negro y lacio esperaba con algo fijo y ávido en la cara sinuosa, en el pliegue de las manos un poco cerradas pero ya

\footnotetext{
${ }^{35}$ Ibídem.

${ }^{36}$ Todo el relato juega con esta ambigüedad, que se hace explícita en pasajes como éstos: "Sólo queda Budapest porque allí es el frío, allí me pegan y me ultrajan. Allí (lo he soñado, no es más que un sueño, pero cómo adhiere y se insinúa hasta la vigilia) hay alguien que se llama Rod"; "Mentira. Soñé a Rod o lo hice con una imagen cualquiera de sueño, ya usada y a tiro", pp. 41 y 42.

37 J. Cortázar (1982), p. 40.

38 "Yo digo: ¿y si estoy? (Porque todo lo pienso con la secreta ventaja de no querer creerlo a fondo. ¿Y si estoy?) Bueno, si estoy... Pero solamente loca, solamente... iQué luna de miel!" J. Cortázar (1982), p. 42.
} 
tendiéndose" ${ }^{39}$, se acerca por fin a la lejana y la abraza, intercambiando en el acto y sin saberlo su identidad con la de su doble:

Le pareció que dulcemente una de las dos lloraba. Debía de ser ella porque sintió mojadas las mejillas, y el pómulo mismo doliéndole como si tuviera allí un golpe. También el cuello, y de pronto los hombros, agobiados por fatigas incontables. Al abrir los ojos (tal vez gritaba ya) vio que se habían separado. Ahora sí gritó. De frío, porque la nieve le estaba entrando por los zapatos rotos, porque yéndose camino de la plaza iba Alina Reyes lindísima en su sastre gris, el pelo un poco suelto contra el viento, sin dar vuelta la cara y yéndose ${ }^{40}$.

Que el cambio de identidad conclusivo no sea la mera proyección de la fantasía de la protagonista ni el efecto de su psicosis está garantizado por la presencia, en el final, de un narrador heterodiegético, de cuyo informe no hay ninguna razón para dudar. Precisamente aquí reside el desvío más relevante con respecto a relatos clásicos del doble como «William Wilson» de Poe o «El sosias» de Dostoievski, ambos basados en un desdoblamiento de tipo alucinatorio, cuyo carácter subjetivo y paranoico emerge de indicios diseminados en diversos puntos del texto y no es cuestionado por ningún punto de vista "externo" al de los protagonistas. Aquí no sólo el personaje, sino el universo del texto actúa de manera esquizofrénica, alternando segmentos perfectamente respetuosos de la lógica clásica y zonas caracterizadas por una elevada simetrización interna, según un modelo parecido al que Matte Blanco denomina alassi. En el interior de un mundo posible perfectamente conforme a la lógica bivalente, el discurso de Alina, luego el del narrador externo, establecen las equivalencias "yo = la otra"; "aquí = allí" (Budapest), infringiendo al mismo tiempo los principios de identidad y nocontradicción ("A es A y no es no-A") y la noción de sucesión espacial tradicional. Cuando luego al final el doble es ratificado en su presencia física y la simetrización que ha operado hasta aquel momento a nivel perceptivo e imaginativo invade la realidad fáctica, el lector se entera de que lo que encubre islas de lógica "confusiva", simétrica, es el mundo mismo instaurado por el relato, y no sólo la psique de la protagonista ni tan sólo las páginas de su diario.

En cuanto a la hipótesis de una "vampirización" mental de Alina por parte de la lejana, que al final triunfaría en el intento de usurpar definitivamente el cuerpo de su víctima, ésta es sin duda plausible en cuanto que explicación retrospectiva, pero no estriba en ninguna alusión textual concreta. El relato, reticente tanto en lo que respecta a la fábula (final abierto), como en lo que concierne a la explicación del acontecimiento fantástico y a la de su significado global, no sólo no dice lo suficiente, sino que no sabe lo suficiente: gracias a un empleo soberbio de la

\footnotetext{
39 J. Cortázar (1982), p. 48.

${ }^{40}$ J. Cortázar (1982), p. 26
} 
ambigüedad sintáctica, invita al lector a participar del escándalo por el que una mujer es sí misma y no es sí misma, es sí misma y otra al mismo tiempo, vive simultáneamente en Buenos Aires y Budapest, sin justificarlo de ninguna manera, ni atribuirlo a una fácil dicotomía moral, psicológica, social. A través de la grieta que surca el mundo posible del relato se insinúa, sin ninguna razón, un magma de sentido indiferenciado, cuya oscuridad acaba por producir, con paradoja sólo aparente, una suerte de "exuberancia semántica", autorizando una multiplicidad de lecturas justo ahí donde parece negarse a cualquier atribución de sentido.

\subsection{Cuando aquí es en otra parte y antes es después: espacios y tiempo simétricos}

Una de las consecuencias que Ignacio Matte Blanco deriva del principio de simetría es el aniquilamiento, dentro del reino de lo simétrico, del espacio y del tiempo:

En matemática y en física, la línea (espacio de una dimensión) se concibe como formada por una serie de puntos [...] En otras palabras, como en el caso del tratamiento físico-matemático del tiempo, esto implica asimetría. En efecto, si $a$ está a la derecha de $b$, entonces $b$ está a la izquierda de $a$. Pero por el principio de simetría, cada vez que $a$ está a la derecha de $b, b$ también está a la derecha de $a$, es más, cada vez que un punto determinado forma parte de una línea determinada, la línea forma parte del punto, es decir, cada punto es idéntico a cualquier otro punto y a toda la línea. En otros términos, si sólo están disponibles relaciones simétricas, el concepto físico-matemático de "línea" desaparece. Lo mismo se puede decir del espacio de dos, tres o más dimensiones. Generalizando, podemos decir que si sólo están disponibles relaciones simétricas, no puede haber espacio en el sentido físico-matemático del término.

De esta manera, por virtud del principio de simetría, ¡tanto el espacio como el tiempo se desvanecen! ${ }^{41}$

Este proceso resulta particularmente patente en la condensación onírica, que Matte Blanco aclara mediante el modelo (operativo y metafórico) de la multidimensionalidad del espacio psíquico: si en sueños es posible advertir que un espacio es sí mismo y otro al mismo tiempo, o que un individuo reúne en sí su propia identidad y la de otra persona, es porque en determinadas ocasiones "el soñador «ve» un mundo multidimensional con ojos hechos para ver sólo un mundo tridimensional" ${ }^{\text {42 }}$, comprimiendo necesariamente hechos y objetos de más dimensiones en un modelo insuficiente para comprenderlos.

${ }^{41}$ I. Matte Blanco (2000), p. 47.

${ }^{42}$ I. Matte Blanco (2000), p. 464. 
Las infracciones lógicas de orden temporal y espacial abundan en la literatura no-realista de cualquier época (recordemos los viajes en el tiempo de la ciencia ficción y la espacialidad mágica de los relatos maravillosos); los efectos que de ello derivan, sin embargo, pueden variar mucho según las convenciones de género y las estrategias discursivas empleadas. Cuando, por ejemplo, un personaje viaja en el tiempo y en el espacio gracias a una máquina del tiempo, o pasa a través de un espejo para acceder a otro mundo en un cuento de hadas, el shock cognitivo que se produce en el lector es exiguo, en el primer caso porque es racionalizado por una explicación posible, si bien no verosímil, en el segundo porque el lector sabe desde el principio que, en el mundo ficcional establecido en el relato, atravesar espejos o levantarse en vuelo son fenómenos aceptados, que no contravienen a ninguna de las normas lógicas vigentes. Lo fantástico contemporáneo presenta, por contra, relatos en los que la intrínseca simetrización espacial o temporal alcanza tales cumbres que no puede ser reconducida a ninguna paráfrasis aceptable, y delante de las cuales el lenguaje analítico está obligado a expresarse por enigmas y paradojas igual de oscuros que los exhibidos por la ficción.

Valga como extraordinario ejemplo de transgresión temporal el relato «Los ganadores de mañana» (1927) del misterioso (¿inexistente?) escritor inglés Holloway Horn, que Borges recoge en la Antología de la literatura fantástica. Martin "Knocker" Thompson, ex manager de peleas de boxeo y partidos de póquer, se topa un día con un desconocido que le regala una copia del periódico de la tarde siguiente, y que por tanto contiene ya todos los ganadores de las carreras de caballos que tendrán lugar al día siguiente. A pesar de sus dudas iniciales, el día después Knocker va al hipódromo de Gatwick y apuesta todo lo que tiene, ganando inmediatamente una fortuna. Pero durante la vuelta en tren, hojeando distraídamente las demás páginas del periódico, encuentra el anuncio de su propia muerte en el mismo convoy, le da un patatús y muere:

De pronto su mirada se detuvo; un suelto le llamó la atención. "Muerte en un tren" se titulaba. El corazón de Knocker estaba agitadísimo; pero siguió leyendo. "El conocido deportista señor Martin Thompson falleció esta tarde en el tren al volver de Gatwick."

No leyó más: el diario se le cayó de las manos.

-Fíjese en Knocker - alguien dijo- . Debe estar enfermo. -

[...] Se sentó, más bien se dejó caer en el asiento. La cabeza se inclinó sobre el pecho.

Le metieron whisky entre los labios, pero era inútil.

— Está muerto - dijo la espantada voz del hombre que lo sostenía ${ }^{43}$.

${ }^{43}$ H. Horn (1981), p. 208. 
El relato está construido en torno a un cortocircuito temporal entre el hoy y el mañana, de tal forma que un fragmento del futuro cercano (el periódico) irrumpe en el presente y condiciona el futuro inmediato del protagonista, que en el espacio de unas pocas horas se vuelve riquísimo y fallece. Ni Knocker ni el narrador heterodiegético arriesgan ninguna interpretación del fenómeno, que por tanto resulta absolutamente aberrante desde el punto de vista lógico, y somete al lector a un dilema no resuelto e insoluble: ¿cómo es posible que mañana (el periódico) sea ya hoy, o que hoy sea ya mañana? Y sobre todo: ¿la muerte del protagonista hubiese sobrevenido en todo caso, y por esto ya estaba registrada en el diario, o en cambio es causada, como parece sugerir el texto, por la lectura misma de la noticia de su propia muerte por parte del protagonista, que se altera hasta tal punto que sufre un infarto y muere de verdad? En otras palabras: ¿es el conocimiento de su propio destino dramático lo que causa y a la vez ratifica aquel destino? ¿Es el futuro lo que aquí determina, subrepticiamente, el presente?

Entre los muchos cuentos fantásticos que contravienen a la noción clásica de espacio, particularmente interesante resulta «Recortes de prensa» de Julio Cortázar (Todos queremos a Glenda, 1980), ilustrativo tanto de la simetrización espacial a la que aludimos como de la densidad semántica en la que puede desembocar la oscuridad que de ella se deriva. En Argentina son los años de la dictadura militar. En París, la escritora argentina exiliada Noemí una noche visita a un connacional escultor y, después de examinar sus últimos trabajos ("una serie de pequeñas esculturas cuyo tema era la violencia en todas las latitudes políticas y geográficas que abarca el hombre como lobo del hombre" ${ }^{44}$ ), consiente de buen grado en redactar un texto de apertura para el catálogo fotográfico de sus obras. A continuación, enseña al escultor unos recortes de prensa (un documento "real", sacado de El País de octubre de 1978) que traen las denuncias de una ciudadana argentina contra el ejército, culpable de la tortura, de la masacre y la desaparición de gran parte de su familia.

De vuelta a su casa, la mujer se topa con una niña llorando, acurrucada en un escalón, la cual, interrogada acerca de la causa de su llanto, contesta: "Mi papá le hace cosas a mi mamá" ${ }^{45}$ y la lleva al interior del edificio, hasta una vivienda de la que vienen gritos reprimidos. Aquí Noemí atisba, a través de una puerta entreabierta, a un hombre torturando con colillas de cigarrillo encendidas el cuerpo desnudo y atado a la cama de su mujer, y sin reflexionar irrumpe en la habitación, arroja un taburete sobre la cabeza del hombre, libera a la víctima y la ayuda a desvestir y atar a su verdugo. Sigue una verdadera venganza, en la que la protagonista participa como en trance, y que la narración remueve en gran parte,

\footnotetext{
${ }^{44}$ J. Cortázar (1981), pp. 65-66.

45 J. Cortázar (1981), p. 74.
} 
reemplazándola con el fragmento de un relato de Jack London en el que se relata la tortura perpetrada por las mujeres de una tribu contra el compañero del protagonista $^{46}$. Luego Noemí huye, bebe vodka para aturdirse, se duerme.

La tarde siguiente, la protagonista escribe un texto en el que relata lo acontecido, luego llama al amigo escultor, le lee parte del informe por teléfono y promete enviarle pronto el texto definitivo como comentario introductorio a su libro fotográfico. Algunos días después, sin embargo, una carta del escultor con un recorte del «France-soir» adjunto le revela una verdad asombrosa: el crimen al que había asistido unas noches atrás no habría acontecido en París, sino, aquella misma noche, en la periferia de Marsella. Los detalles mencionados en el artículo ("drama atroz en un suburbio de Marsella, descubrimiento macabro de un crimen sádico, ex plomero atado y amordazado en un camastro, el cadáver etcétera, vecinos furtivamente al tanto de repetidas escenas de violencia, hija pequeña ausente desde días atrás"47) y la foto de la vivienda no dejan lugar a dudas. Cuando vuelve al lugar del suceso, Noemí ya no encuentra la entrada por la que había penetrado aquella noche y no se sorprende ("no reconocí ningún portal que se pareciera al de esa noche [...] ningún acceso a un huerto interior, sencillamente porque ese huerto estaba en los suburbios de Marsella" ${ }^{, 48}$ ); sin embargo, ve a la misma niña sentada en el escalón de la entrada, la cual, como le explica la portera, habría aparecido misteriosamente por ahí algunos días atrás y ahora estaría a la espera de los asistentes sociales. Aquí se cierra, sin cerrarse, el relato.

Aparentemente realista hasta un paso de la conclusión pero descubierto en el final como lógicamente imposible y contradictorio, el relato presenta una fábula clara en todas sus partes salvo en las indicaciones espaciales, con respecto a las cuales hace valer una momentánea simetrización por la que "aquí = allí" ("París = Marsella"), oscura tanto en sus razones inmediatas (la convergencia entre los dos espacios acontece sin más, no es propiciada por un hechizo, ni vehiculada por un milagro o un experimento pseudo-científico) como en su significado general en el texto. Un examen cuidadoso del relato, sin embargo, permite arrojar luz sobre su extraordinaria densidad semántica y comprender el valor que la transgresión lógica, inexplicable en sí, adquiere en un plano de lectura "simbólico".

Varias alusiones diseminadas en el texto desde su íncipit dejan entrever dos discursos dominantes, en torno a los cuales se erige el entero aparato de sentido del relato. El primero es un discurso meta-narrativo y en general meta-artístico, que concierne por un lado a la representabilidad de la violencia en el arte, por otro a la relación entre el artista y la Historia, y en particular entre el artista exiliado y el presente histórico de su país. Punto focal del primer "subdiscurso" es la fugaz mise

\footnotetext{
${ }^{46}$ El relato, al que Cortázar alude sin nombrarlo, es «Lost Face» («El burlado», 1910).

${ }^{47}$ J. Cortázar (1981), pp. 80-81.

${ }^{48}$ J. Cortázar (1981), p. 81.
} 
en abyme en la que Noemí se interroga sobre la manera más adecuada y menos dudosa de representar la tortura, remitiendo de hecho al carácter oscuro y enigmático del relato que estamos leyendo y que no es más, como descubriremos más tarde, que el texto que la escritora entrega al escultor para su volumen:

Me gustó que en el trabajo del escultor no hubiera nada de sistemático o demasiado explicativo, que cada pieza contuviera algo de enigma y que a veces fuese necesario mirar largamente para comprender la modalidad que en ella asumía la violencia; las esculturas me parecieron al mismo tiempo ingenuas y sutiles, en todo caso sin tremendismo ni extorsión sentimental. Incluso la tortura [...] no había sido mostrada con la dudosa minucia de tantos afiches y textos y películas que volvían a mi memoria también dudosa, también demasiado pronta a guardar imágenes y devolverlas para vaya a saber qué oscura complacencia. Pensé que si escribía el texto que me había pedido el escultor, si escribo el texto que me pedís, le dije, será un texto como esas piezas, jamás me dejaré llevar por la facilidad que demasiado abunda en este terreno ${ }^{49}$.

El problema de la relación entre los artistas y la realidad histórica, y específicamente el interrogante por la posibilidad del arte de intervenir en ella concretamente, aún más apremiante para el artista exiliado que se encuentra actuando a distancia, aflora en el diálogo entre los dos amigos. La lectura del recorte, en efecto, reaviva las dudas del escultor sobre la utilidad social de su trabajo, y sobre su condición de exiliado:

\begin{abstract}
Ya ves, todo esto no sirve de nada [...] No sirve de nada, Noemí, yo me paso meses haciendo estas mierdas, vos escribí libros, esa mujer denuncia atrocidades, vamos a congresos y a mesas redondas para protestar, casi llegamos a creer que las cosas están cambiando, y entonces te bastan dos minutos de lectura para comprender de nuevo la verdad, para... [...] Y yo estoy aquí a miles y miles de kilómetros discutiendo con un editor qué clase de papel tendrán que llevar las fotos de las esculturas, el formato y la tapa [...] siempre es igual, siempre tenemos que reconocer que todo eso sucedió en otro espacio, sucedió en otro tiempo. Nunca estuvimos ni estaremos alli, donde acaso... ${ }^{50}$
\end{abstract}

Sin embargo, en el piso parisino del escultor, la lectura del recorte de prensa parece abolir provisionalmente la distancia que separa París y Buenos Aires, y por el espacio de algunos instantes el repiqueteo de un reloj de pared propicia la sensación de una continuidad espacial entre los dos lugares:

\footnotetext{
49 J. Cortázar (1981), pp. 66-67, cursivas mías.

${ }^{50}$ J. Cortázar (1981), pp. 69-70 y p. 71, cursivas mías.
} 
[...] el leve sonido me llegaba como un metrónomo de la noche, una tentativa de mantener vivo el tiempo dentro de ese agujero en que estábamos como metidos los dos, esa duración que abarcaba una pieza de París y un barrio miserable de Buenos Aires, que abolía los calendarios y nos dejaba cara a cara frente a eso, frente a lo que solamente podíamos llamar eso, todas las calificaciones gastadas, todos los gestos del horror cansados y sucios ${ }^{51}$.

El segundo discurso dominante en el relato es un discurso complejo sobre la violencia, explorada a la luz de su ubicuidad y de la reversibilidad de los papeles inherente a su ejercicio. La tortura que el ejército aplica a los disidentes argentinos es algo que acontece, es cierto, "en otro espacio, [...] en otro tiempo" ${ }^{, 2}$, pero esencialmente se repite, bajo otra forma y por motivos diferentes, en la vivienda de una familia francesa. El hecho de que el crimen tenga lugar en Marsella y en París simultáneamente (o sólo en Marsella, pero de tal forma que la protagonista lo ve en París) quita cualquier pertinencia a la notación espacial: el aquí y el allí, París y Marsella, Francia y Buenos Aires se vuelven elementos intercambiables, en un discurso sobre la tortura que trasciende las fronteras espaciales para significar la universalidad de la dinámicas psíquicas que están en juego. La simetrización "aquí = allí" que constituye el núcleo del relato, se refleja y se articula en aquella, no fantástica porque llevada a cabo de forma discursiva, "nosotros = ellos", equivalencia que la protagonista descubre en el momento en el que deja de ser simple espectadora de la violencia, irrumpe en la escena y participa en la venganza.

Durante la tortura, Noemí es literalmente "actuada" por un nosotros colectivo, y es ese nosotros -y no ella como individuo- el que cede a la violencia y toma parte en la venganza. Lo demuestra claramente un pasaje del relato en el que la descripción de la escena está alternada con imágenes y frases sacadas de las denuncias del primer recorte de prensa:

[...] como nosotras jamás descritas y haciendo lo que debíamos, lo que teníamos que hacer. Inútil preguntarse ahora por qué estaba yo en eso, cuál era mi derecho y mi parte en eso que sucedía bajo mis ojos que sin duda vieron, que sin duda recuerdan [...] Sólo sé que la nena no estaba con nosotras desde mi entrada en la pieza, y que ahora la mamá le hacía cosas al papá, pero quién sabe si solamente la mamá o si eran otra vez las ráfagas de la noche, pedazos de imágenes volviendo desde un recorte de diario, las manos cortadas de su cuerpo y puestas en un frasco que lleva el número 24, por informantes no oficiales nos hemos enterado que falleció súbitamente en los comienzos de la tortura $[\ldots]^{53}$.

51 J. Cortázar (1981), p. 68, cursivas mías.

52 J. Cortázar (1981), p. 71.

53 J. Cortázar (1981), p. 78, cursivas mías. 
Aun así, el envolvimiento de Noemí en la venganza, o mejor el contagio, impulsivo e irracional, que sobre ella opera el mecanismo de la tortura, es descrito sin apartar nunca la mirada de su inaceptabilidad ética, es más, recalcando la contradicción emocional en la que se encuentra atrapada la narradora:

Cómo saber cuánto duró, cómo entender que también yo, también yo aunque me creyera del buen lado también yo, cómo aceptar que también yo ahí del otro lado de manos cortadas y de fosas comunes, también yo del otro lado de las muchachas torturadas y fusiladas esa misma noche de Navidad $[\ldots]^{54}$

La infracción lógica que opera en el relato debe ser comprendida a la luz de estos dos discursos dominantes, los cuales encuentran en ella una suerte de realización fantástica, cuya finalidad no es, sin embargo, ilustrarlos, sino complejizarlos aún más: a la tesis del escultor sobre la distancia del exiliado de los lugares de los crímenes y la consiguiente imposibilidad para actuar, el relato opone una indiferenciación entre el aquí y el allí que, referida a la distancia París-Marsella, se extiende idealmente a la distancia entre París y Buenos Aires, expresando al mismo tiempo la ubicuidad de la violencia y la necesidad de reconocerla también aquí, instalada en el corazón del nosotros. Aquí (París) como allí (Buenos Aires) el artista puede actuar, porque aquí (París) como allí (Marsella), como allí (Buenos Aires) se practica la tortura y la violencia desencadena, en quienes participan en ella, las mismas dinámicas psíquicas. La equivalencia nosotros-ellos (víctimas-verdugos) es aludida por vía metafórica y no da lugar a ninguna simetrización fantástica (el torturador y las dos mujeres se cambian de papel sin que sus identidades sufran una efectiva inversión, como ocurre por ejemplo en Lejana), pero la infracción espacial con la que se combina dicho cambio de rol potencia su efecto y lo enlaza con una reflexión más amplia.

El carácter oscuro de la infracción lógico-espacial y la rigurosa reticencia explicativa y semántica que el cuento observa al relatarla, hacen que el conglomerado de imágenes que de ello resulta se escape de un discurso unitario, definitivo, sobre los temas tratados. Al someter a los lectores a una historia enigmática "precisamente lo que Noemí deseaba que fuera su texto introductorio al volumen" el relato hace estallar y chocar uno contra otro los interrogantes más apremiantes sobre la violencia (la legitimidad de la venganza, la reversibilidad de la relación verdugos-víctimas, la equiparabilidad de las culpas, la ubicuidad del mal), dejando al lector la tarea de buscar, construyéndola, una respuesta.

\subsection{Pars pro toto y causalidad fantástica}

${ }^{54}$ J. Cortázar (1981), pp. 78-79. 
Uno de los corolarios más relevantes del principio de simetría es, como se ha mencionado, la equivalencia entre la parte $\mathrm{y}$ el todo, y la consiguiente intercambiabilidad de los diversos miembros de la misma clase bajo la acción disolvente de lo simétrico. De ahí deriva que, además de desmantelar la idea de espacio y tiempo, el principio de simetría indirectamente corroe, donde se aplica, la noción clásica de causalidad, concebible tan sólo a condición de que existan relaciones rigurosas y estables entre los objetos. A este respecto, el principio simétrico según el cual el todo está contenido en cada una de sus partes y cada parte es idéntica a todas las demás revela una asombrosa convergencia con lo que muchos etnólogos e historiadores de las religiones han definido, más allá de las especificidades históricas y culturales, el pensamiento mágico, y que puede ser considerado como la formulación "intuitiva" de la mismas leyes psíquicas a las que llega Matte Blanco. En particular los estudios estructurales de Lévy-Bruhl y Ernst Cassirer sobre la mentalidad mágica destacan la predominancia, en las culturas de muchos pueblos así llamados "primitivos", de una lógica basada en leyes de participación, "impermeable a la experiencia y creadora de nexos de afinidad, de simpatía, de eficacia o de identidad sustancial entre fenómenos y objetos en realidad recíprocamente independientes" $" 55$, alternativa a la lógica tradicional basada en la observación empírica y en el principio de identidad.

Conforme a la mentalidad mágica, cada parte no sólo representa, sino que literalmente es el todo: de esto se deduce que ésta está vinculada a las demás partes de la misma totalidad por un nexo "causal" desconocido por la lógica tradicional; la relación mágica de la simpatía descuidaría además, según Cassirer, la sucesión temporal, estableciendo relaciones causales indiferentes a la concatenación de las causas y los efectos en el tiempo ${ }^{56}$. Del carácter "confusivo" o sincrético de las

\footnotetext{
${ }^{55}$ E. de Martino (1965), p. 65.

${ }^{56}$ Véase el ejemplo mencionado por Cassirer: "Si un guerrero es herido por una flecha, según la concepción mágica se puede curar o puede disminuir su dolor colgando una flecha en un lugar ameno o embadurnándola de ungüento [...] Desde el punto de vista del pensamiento científico, una cosa única no es nunca simplemente la causa de otra, sino que su efecto sólo se produce en muy precisas circunstancias determinadas, y sobre todo en un momento temporal rigurosamente delimitado. La relación causal no es tanto una relación entre cosas, cuanto más propiamente una relación entre mutaciones que acaecen en ciertos objetos dentro de tiempos bien establecidos [...] La flecha, entonces, no puede ya ser considerada como la causa de la herida; más bien la flecha, en el preciso momento $\mathrm{t}^{1}$ en que penetra en el cuerpo, provoca en él una determinada mutación a la cual luego [...] se vinculan otras series de mutaciones orgánicas que deben ser todas ellas necesariamente consideradas como condiciones parciales de la herida. Desde el momento en que el mito y la magia no emprenden nunca este análisis de las condiciones parciales, cada una de las cuales sólo posee un específico valor relativo a la totalidad de la relación causal, se sigue de ello que ni el mito ni la magia distinguen netamente ni los momentos temporales ni las partes de una totalidad espacial.” E. Cassirer (1965), pp. 73-74.
} 
conexiones lógicas derivaría, finalmente, aquella característica del pensamiento mágico por la cual el sujeto (el adulto "primitivo", el niño, el adulto neurótico y el psicótico) sería incapaz de discernir entre pensamiento y cosas, es decir, entre yo y mundo externo, y tendería a sustituir las leyes naturales por leyes psíquicas, según el principio que Freud denominó, en su lectura pionera del fenómeno, la omnipotencia de las ideas ${ }^{57}$.

Los relatos fantásticos que remiten a una concepción mágica, o simétrica, de las relaciones causales son muy numerosos, como supo ver con asombrosa claridad Freud en su iluminador ensayo sobre «El hombre de arena» de Hoffmann ${ }^{58}$ : al buscar el origen del sentimiento de lo unheimlich (siniestro) que emana tanto de situaciones reales como, más frecuentemente, de relatos de ficción ubicados en el mundo común en los que sin embargo acontecen sucesos increíbles, Freud lo rastrea en la pervivencia de una visión animista (es decir, mágica) del universo, la cual, si bien reprimida y superada tanto a nivel individual como colectivo (en el niño y en la cultura), en ocasiones volvería a aflorar en el sujeto presentándosele como algo a la vez familiar (heimlich) y desconocido, por lo tanto siniestro, pertubador (unheimlich).

Como ya se ha observado con respecto a las transgresiones "identitarias" y espacio-temporales, sin embargo, hay que destacar que, mientras que la mayoría de los relatos fantásticos tradicionales se refiere al sistema conceptual de la magia de forma explícita, produciendo así imágenes culturalmente transparentes y decodificables, el relato fantástico del siglo XX tiende a transgredir la noción de causalidad sin remitir a códigos interpretativos preestablecidos, por medio de una simetrización de los nexos causales destinada a generar imágenes oscuras y polisémicas. En la cuentística cortazariana, uno de los ejemplos más paradigmáticos de dicha causalidad fantástica es «Verano» (Octaedro, 1974), un relato construido en torno a un acontecimiento en rigor no lógicamente imposible, pero basado en un régimen causal hasta tal punto misterioso, inescrutable en sus mecanismos, que el cuento puede ser considerado a todos los efectos como fantástico.

Una pareja en crisis aloja en su casa de campo, durante un día y una noche, a la hija de un amigo, cuya presencia los arranca durante unas horas de la monotonía de su convivencia. Por la noche, después de acostar a la niña en una camita preparada en la cocina, los dos protagonistas oyen de repente un ruido extraño, "casi como un bufido" ${ }^{\text {, }}$, y al rato les aparece un enorme caballo blanco:

Es un caballo, dijo Mariano sin creerlo, suena como un caballo, oí los cascos, está galopando en el jardín. Las crines, los belfos como sangrantes, una

${ }_{58}^{57}$ Cfr. S. Freud (2006b).

${ }^{58}$ S. Freud (2006c).

${ }^{59}$ J. Cortázar (1974), p. 73. 
enorme cabeza blanca rozaba el ventanal, el caballo los miró apenas, la mancha blanca se borró hacia la derecha, oyeron otra vez los cascos, un brusco silencio del lado de la escalera de piedra, el relincho, la carrera. Pero no hay caballos por aquí, dijo Mariano que había agarrado la botella de aguardiente por el gollete antes de darse cuenta y volver a ponerla sobre la banqueta ${ }^{60}$.

Las reacciones de los protagonistas ante la aparición, inusual pero no espantosa, son absolutamente excesivas e impresionan precisamente por su desproporción con respecto a la conducta que nos esperaríamos de ellos en una situación semejante. Zulma es presa de un pánico inexplicable, sordo a cualquier intento del marido de tranquilizarla, y repite sollozando, con insistencia casi autista, que el caballo quiere entrar en la casa ("Quiere entrar, dijo Zulma pegada a la pared del fondo [...] Te digo que quiere entrar, está rabioso y quiere entrar" "61; "Va a entrar, murmuró Zulma [...] Oh sí, dijo Zulma, quiere entrar, va a aplastarnos contra las paredes, sé que quiere entrar [...] Va a volver, dijo Zulma con los ojos clavados en el ventanal [...] Ningún caballo hace eso, dijo Zulma, ningún caballo quiere entrar así en una casa"62). Por su parte, Mariano tiene reacciones no menos exasperadas: "Sh, dijo Mariano, cállate, por favor [...] Y no tengo ni una escopeta, dijo Mariano, le metería cinco balas en la cabeza, hijo de puta."; "Sh, repitió Mariano que también lo pensaba, que no podía hacer otra cosa que esperar con la espalda empapada de sudor frío" $"$.

Mientras tanto, en su cama, la niña "dormía increíblemente y no había escuchado nada" "64. Zulma acaba acostándose pero se despierta al rato por una pesadilla, vuelve a bajar e insiste en su obsesión, convencida de que la niña quiere dejar entrar en casa al caballo: "En la mitad de la escalera Zulma se detuvo, tomándose de la barandilla. ¿Vos sabés por qué está ahí la nena? Con una voz que debía pertenecer todavía a la pesadilla. ¿La nena? [...] Zulma, por favor. Y la voz quebrada, casi en falsete, está ahí para dejarlo entrar, te digo que lo va a dejar entrar" ${ }^{\prime 65}$. La pequeña, interrogada con brutalidad, aclara que se ha levantado para ir al baño. Entonces Mariano lleva a su mujer a la cama casi por la fuerza, y aquí la posee contra su voluntad. Cuando se levanta la mañana siguiente, se percata de que por la noche la niña efectivamente ha abierto la puerta al caballo, pero éste no ha entrado, y parece que ha desaparecido; “A menos que sí, lo pensó encendiendo el primer cigarrillo y mirando el filo azul de las colinas, a menos que también en eso Zulma tuviera razón y que el caballo hubiera entrado en la casa, pero cómo saberlo

\footnotetext{
${ }^{60}$ Ibídem.

${ }^{61}$ Ibídem.

${ }^{62}$ J. Cortázar (1974), pp. 74-75.

63 J. Cortázar (1974), pp. 74 y 75.

${ }^{64}$ J. Cortázar (1974), p. 75.

${ }^{65}$ J. Cortázar (1974), p. 77.
} 
si no lo habían escuchado, si todo estaba en orden" ${ }^{\text {"66 }}$. Tras la salida de la niña, en efecto, en la vida de los protagonistas vuelve a instalarse el orden y la rutina retoma su curso.

Antes de la llegada de la niña y la aparición del caballo, el narrador nos describe la vida de la pareja como una serie de "múltiples nimias delicadas ceremonias convencionales" y "repeticiones previsibles" "67; cualquier voluntad de un auténtico diálogo se ha apagado desde hace tiempo ("Solamente que ya no lo decía en voz alta, cada vez parecía haber menos necesidad de hablar con Zulma, y Zulma tampoco decía nada que reclamara un cambio de ideas" ${ }^{98}$ ) y la mujer vive aislada en una "lejanía petrificada"69. Los dos, sin embargo, no son conscientes de su crisis sino en parte, y es sólo con la aparición concomitante de la niña y del caballo cuando su relación recibe una sacudida improvisa y se ve obligada, aunque sólo sea por algunas horas, a mirarse en el espejo.

Que el caballo no sea la mera alucinación o pesadilla de uno de los personajes es confirmado por Mariano, que inspeccionando el jardín reflexiona absurdamente: "no era una alucinación, entonces, y desde luego valía más que no lo fuera ${ }^{70}$. El animal constituye, sin duda, de acuerdo con una larga tradición iconográfica, un símbolo del deseo sexual, pero esto no impide que sea también un caballo de carne y hueso, un caballo real, que del lado violento y siniestro de aquel deseo representaría la personificación o "realización" fantástica. Interpretar a la figura del caballo como la encarnación de un sentimiento determinado, sin embargo, resulta simplificador: si se mira bien, ése no representa tan sólo el deseo reprimido, ni la ira de Mariano, ni el terror de Zulma, ni su recíproca exasperación, o incluso animadversión, que intuimos debajo de tanta costumbre, tanto afecto y aburrimiento; sino que es un "precipitado" de todos estos aspectos, amontonados y superpuestos en una imagen oscura, que importa más por las reacciones que provoca en la vida de los protagonistas y por la cuota de desorden que introduce en ella, que por su específico valor metafórico.

Recibida por Zulma con verdadero horror, la intrusión del caballo en la existencia inmóvil de la pareja lleva a un acto de violencia detrás del cual se intuyen juegos de fuerza y resistencias antiguas:

No importa, dijo Mariano, que entre si quiere, ahora me importa un carajo que entre o no entre. Atrapó las manos de Zulma que buscaban rechazarlo, la empujó de espaldas contra la cama, cayeron juntos, Zulma sollozando y suplicando, imposibilitada de moverse bajo el peso de un cuerpo que la ceñía cada vez más,

\footnotetext{
${ }^{66}$ J. Cortázar (1974), p. 79.

${ }^{67}$ J. Cortázar (1974), pp. 70 y 71.

${ }^{68}$ J. Cortázar (1974), p. 72.

${ }^{69}$ J. Cortázar (1974), p. 77.

${ }^{70}$ J. Cortázar (1974), p. 76, cursivas mías.
} 
que la plegaba a una voluntad murmurada boca a boca, rabiosamente, entre lágrimas y obscenidades. No quiero, no quiero, no quiero nunca más, no quiero, pero ya demasiado tarde, su fuerza y su orgullo cediendo a ese peso arrasador que la devolvía al pasado imposible, a los veranos sin cartas y sin caballos ${ }^{71}$.

La solidaridad secreta entre el caballo y la niña no encuentra ninguna explicación en el texto: la coincidencia por la que irrumpen simultáneamente en la vida de los protagonistas y el deseo de la niña de dejar pasar el caballo podrían ser del todo causales, o brotar de la visión paranoica de Zulma, que confunde una mera casualidad con una conexión causal (niña-caballo). El relato, sin embargo, insiste tanto, si bien de forma oblicua y reticente, en el vínculo misterioso entre los dos acontecimientos, que induce a sospechar de una efectiva connivencia entre el animal y la niña, y sugiere la acción de una causalidad fantástica subyacente.

Julio Cortázar, por otra parte, nunca ocultó su natural aversión a las leyes aristotélicas, y su esencial desconfianza en el intelecto como único instrumento de comprensión del mundo: "Mi noción del tiempo y del espacio, que determina la de causalidad," declaró en una entrevista, "la relación de causa y efecto en el tiempo y en el espacio, para mí todo esto no se cae en absoluto por su propio peso [...] hay causas que ocasionan efectos absolutamente imprevistos para la lógica aristotélica, y algunos así llamados efectos correspondientes a un sistema de causas que no es el que aparentemente debería haberlos determinado" 72 . El término clave para comprender dicha concepción causal es figura, con el que el escritor designa una constelación de causas y efectos reglada por un principio misterioso, que sólo a raíz de la insuficiencia de la lógica clásica para describirla percibimos como caótica y aleatoria $^{73}$, y en la que no es difícil vislumbrar una versión personal del principio mágico de la participación y de la ley lógica de la simetría que se ha tratado de esbozar hasta aquí. En el relato fantástico que acabamos de analizar, dicho principio genera un conglomerado de imágenes (crisis conyugal, deseo reprimido o adormecido, caballo, niña) cuya recíproca relación causal se escapa a cualquier paráfrasis coherente y desemboca forzosamente en una multiplicidad de lecturas.

\subsection{Confusión entre abstracto y concreto y palabras como cosas}

Pese a que Matte Blanco no trate la cuestión explícitamente, de su teoría se deduce fácilmente que las categorías de abstracto y concreto pierden, a ciertas profundidades del inconsciente y de lo real, toda posibilidad de ser distinguidas. Ya Freud había incluido entre las propiedades del inconsciente la sustitución de la

${ }_{71}^{71}$ J. Cortázar (1974), pp. 78-79.

72 J. Cortázar, cit. en B. Terramorsi (1994), p. 17, trad. mía.

${ }^{73}$ Para una formulación sistemática de la idea de figura, véase en particular J. Cortázar (2005). 
realidad externa por la psíquica, y había destacado como rasgos típicos del pensamiento que él denominaba "animista" el "tomar por error una relación ideal por una relación real" 74 y el "predominio concedido a los procesos psíquicos" ${ }^{\text {"75. Por }}$ el principio llamado de la "omnipotencia del pensamiento", tanto el "primitivo" como el sujeto neurótico y el psicótico (conforme a un enfoque que en el síntoma psíquico destaca el perpetuarse de formas del pensamiento culturalmente "superadas") tenderían a confundir el mundo exterior con su propia realidad psíquica, proyectando sus procesos mentales en la realidad y atribuyéndoles una existencia independiente.

En la Interpretación de los sueños, además, Freud destacaba que las palabras y las frases suelen perder, en el sueño, su función abstractiva, y acaban por ser tratadas al igual que simples objetos: "La labor de condensación del sueño se hace más que nunca evidente cuando toma objetos palabras y nombres. Las palabras son tratadas con frecuencia por el sueño como si fueran cosas, y sufren entonces iguales uniones, desplazamientos, sustituciones y condensaciones que las representaciones de cosas. Resultado de estos sueños es la creación de formaciones verbales singularísimas y a veces muy cómicas" ${ }^{\text {76 }}$.

La disolución simétrica de las fronteras entre el término abstracto y el concreto, y en particular entre el objeto y la palabra que lo designa, puede ser inferida del principio de equivalencia entre la parte y el todo, considerando el nombre como una parte de la identidad del objeto ${ }^{77}$; o se puede deducir del principio de generalización, el cual, llevado a sus consecuencias extremas, siempre permite establecer una clase comprensiva de los términos considerados, trazando así equivalencias entre entidades situadas en vertientes opuestas como cosa/reflejo, sujeto/retrato, símbolo/simbolizado. La idea de que sea posible crear o destruir mediante la nominación y en general influir en la realidad externa por medio del empleo ritual de la palabra, que la mentalidad mágica comparte con algunas religiones, subyace en diversos relatos fantásticos orientados a la subversión de la relación habitual entre palabras y cosas: en algunos de ellos, sin embargo, como se ha destacado con respecto a las infracciones lógicas anteriores, el procedimiento es

\footnotetext{
74 S. Freud (2006b), p. 1797.

${ }^{75}$ S. Freud (2006b), p. 1802.

${ }^{76} \mathrm{~S}$. Freud (2006), p 527.
}

77 Sobre el uso del nombre entre los pueblos "primitivos", destaca Freud: "Según los primitivos, constituye el nombre una parte esencial de la personalidad. Así, pues, el conocimiento del nombre de una persona o de un espíritu procura ya un cierto poder sobre ellos. De aquí todas las singulares precauciones y restricciones que deben observarse en el uso de los nombres, y de las que ya hemos enumerado algunas en el capítulo dedicado al tabú. En estos casos queda reemplazada la analogía por la sustitución de la parte al todo." S. Freud (2006b), p. 1799. 
manifiesto y el modelo mágico sugiere una explicación al fin y al cabo aceptable; en otros, por el contrario, una fuerte reticencia explicativa frustra cualquier tentativa "tranquilizadora" de interpretación, confiriendo al acontecimiento fantástico una "negatividad semántica" casi absoluta.

La narrativa cortazariana ofrece numerosos ejemplos de confusión entre la realidad psíquica y la externa, en los que un producto mental acaba por cobrar, fantásticamente, existencia real, y en cierto sentido se puede decir que la mayor parte de la producción fantástica de Cortázar estriba en la "traducción en términos de realidad" de contenidos psíquicos más o menos inconscientes: acontecimientos inexplicables como el hecho de vomitar conejitos («Carta a una señorita en París», Bestiario, 1951), la transformación de un hombre en axolotl («Axolotl», Final del juego, 1956), la invasión por parte de seres innominados de una casa donde dos hermanos viven entregados a una relación sutilmente incestuosa («Casa tomada», Bestiario, 1951), etc., pueden ser considerados como la "actualización” fantástica de aspectos inconscientes de la psique de sus protagonistas (y del mismo Cortázar, como el escritor admitió en diversas entrevistas). Sin embargo, hay casos en los que la procedencia mental del objeto o suceso fantástico es explícita, y va acompañada por una tematización deliberada del aspecto verbal y del poder "generativo" del lenguaje.

Es el caso de «Lejana», en que el doble imaginado o alucinado por Alina Reyes brota literalmente del anagrama "Alina Reyes/ es la reina y...", y es el de «Satarsa» (Deshoras, 1982), en el que el monstruo que da título al relato, el rey de las ratas contra las que luchan desesperadamente los personajes, es generado por un palíndromo ideado por el protagonista:

- Pero si lo pensás en plural todo cambia. Atar a las ratas no es lo mismo que atar a la rata.

- No parece tan diferente $[\ldots]$ ¿Qué tiene de nuevo?

- Tiene que atar a las ratas te da Satarsa la rata.

- ¿Satarsa?

- Es un nombre, pero todos los nombres aíslan y definen. Ahora sabés que hay una rata que se llama Satarsa. Todas tendrán nombres, seguro, pero ahora hay una que se llama Satarsa ${ }^{78}$.

Otro fantasma lingüístico "literalizado", en el que la diferencia entre verbum y res queda borrada y un síntoma es traducido en términos de realidad fantástica, es la misteriosa mancuspia. Libremente inspirado en un artículo (existente) de la profesora Tyler sobre las cefaleas y sus posibles remedios homeopáticos, que el relato cita en el epígrafe, «Cefalea» (Bestiario, 1951) de Julio Cortázar es un relato deliberadamente enigmático, tan reticente que deja en la sombra el número exacto

78 J. Cortázar (2004), p. 46. 
de sus protagonistas (el narrador encarna un "nosotros" colectivo del que no se consigue identificar el número ni el género), la causa y finalidad de sus acciones, las razones de la quiebra final de su proyecto. Todo lo que se puede deducir es que en un mundo posible ligeramente diferente del mundo real (un mundo en el que las mancuspias existen, y nadie se sorprende de ello), un grupo de personas cría desde hace meses, en un lugar retirado, unos mamíferos peludos, dotados de pico y manos y capaces de aullar, necesitados de un cuidado constante y misteriosamente responsables de las terribles cefaleas que afligen a los protagonistas, tanto más agudas cuanto más ellos se acercan a los animales.

Sin embargo, el vínculo que une las mancuspias a las cefaleas -cuyos cuadros clínicos están descritos meticulosamente, en relación con cada uno de los personajes $^{79}$ - no es un simple nexo de causa-efecto: las mancuspias, de hecho, están descritas como auténticas personificaciones de las migrañas que sufren sus criadores. La confusión entre el dolor de cabeza y el estruendo producido, fuera, por los animales, se acentúa a medida que se intensifica el cansancio y se agudizan los síntomas: "No pensamos en salir, demasiado es estar oyéndolas, uno de nosotros de si los alaridos son fuera o aquí porque hay momentos en que nacen como desde dentro, y a lo largo de esa hora entramos en un cuadro Aconitum donde todo se confunde y nada es menos cierto que su contrario" ${ }^{\$ 0}$. En el ápice del malestar, finalmente, la identificación entre realidad externa y realidad interna es completa y cualquier diferencia entre las mancuspias y las cefaleas pierde significado:

El cráneo comprime el cerebro como un casco de acero - bien dicho. Algo viviente camina en círculo dentro de la cabeza. (Entonces la casa es nuestra cabeza, la sentimos rondada, cada ventana es una oreja contra el aullar de las mancuspias ahí afuera.) [...] No estamos inquietos, peor es afuera, si hay afuera. Por sobre el manual nos estamos mirando, y si uno de nosotros alude con un gesto al aullar que crece más y más, volvemos a la lectura como seguros de que todo esto está ahora ahí, donde algo viviente camina en círculo aullando contra las ventanas, contra los oídos, el aullar de las mancuspias muriéndose de hambre ${ }^{81}$.

El relato termina así, con una simetrización perfecta entre el adentro (la cabeza de los protagonistas) y el afuera (la casa), y entre los seres que infestan la casa (las

\footnotetext{
79 Véanse los ejemplos siguientes: "Uno de nosotros es Aconitum [...] El otro, en cambio, es marcadamente Nux Vomica"; "Si uno de nosotros salta de la cama antes que el otro, puede ocurrir con todo que asistamos consternados a la repetición de un fenómeno de Camphora monobromata [...] Tal vez en secreto seamos un poco Natrum muriaticum". J. Cortázar (1982a), pp. 68-69.

${ }^{80}$ J. Cortázar (1982a), p. 79.

${ }^{81}$ J. Cortázar (1982a), p. 84.
} 
mancuspias) y los que han tomado posesión de las cabezas de los personajes (las cefaleas). Probablemente exterminar a las mancuspias equivaldría a poner fin a las migrañas, como curar el dolor de cabeza causaría la desaparición de las mancuspias. Pero el lector no dispone de ningún final cerrado; no comprende, a causa de una reticencia explicativa absoluta, el porqué del acontecimiento fantástico (la misteriosa relación entre las mancuspias y las cefaleas); ni consigue atribuir a las mancuspias y a su extraño poder un valor metafórico determinado (reticencia semántica). Símbolos de una angustia sin nombre, representaciones tangibles del dolor, metáforas de lo absurdo de la existencia y de la invencible soledad humana, etc., las mancuspias albergan, en su casi absoluta negatividad semántica ("no tienen ningún sentido"), una riqueza de significados muy amplia si no inagotable, que ninguna paráfrasis lineal podría anclar a una explicación satisfactoria.

Para sintetizar lo expuesto hasta aquí, diremos que existe transgresión "sin fantástico" (como demuestran muchos relatos realistas caracterizados por contenidos culturalmente subversivos o novedades formales revolucionarias), pero no existe fantástico sin transgresión. Dicha transgresión, sin embargo, opera de forma muy diferente en el género fantástico clásico y en el contemporáneo: mientras que en la literatura fantástica del siglo XIX la aparente violación de los códigos culturales vigentes acababa por actuar en un sentido conservador con respecto al paradigma de realidad dominante, el relato fantástico más innovador del siglo XX lleva a cabo una transgresión radical, irreductible a una enciclopedia determinada o a una teoría coherente, y por lo tanto reacia a cualquier paráfrasis racional y unívoca.

Combinando transgresión semántica ( $=$ rechazo de la significación) y transgresión lógica (= infracciones de las nociones de identidad, espacio, tiempo, causa y diferencia concreto/abstracto) mediante un empleo estratégico de la reticencia a cualquier nivel, la escritura de autores como Kafka, Borges, Bioy Casares, Silvina Ocampo, Dino Buzzati, y destacadamente Julio Cortázar, construye enigmas que sacuden las certezas de la cultura, desembocando, en el plano metafórico o simbólico, en una pluralidad "indecidible" de interpretaciones. De tal manera que el vacío de sentido se vuelve euforia semántica, y la frustración del lector acaba siendo su fiesta.

\section{Obras citadas}

CAILlOIS, Roger: De la féerie à la science fiction, trad. it. Dalla fiaba alla fantascienza, Paolo Repetti (Ed.), Roma, Theoria, 1985.

- Au coeur du fantastique, trad. it. Nel cuore del fantastico, Milano, Abscondita, 2004.

CAMPRA, Rosalba: Territorios de la ficción. Lo fantástico, Sevilla, Renacimiento, 2008. 
CASSIRER, Ernst: «Espacio, tiempo y causalidad de la magia», en Ernesto de Martino (Ed.), Magia y civilización, Buenos Aires, El Ateneo, 1965.

CORTÁZAR, Julio: «Verano», en Octaedro, Madrid, Alianza, 1974.

— «Recortes de prensa», en Queremos tanto a Glenda, Madrid, Alfaguara, 1981.

— «Lejana», en Bestiario, Madrid, Alfaguara, 1982.

— «Cefalea», en Bestiario, Madrid, Alfaguara, 1982a.

- «Satarsa», en Los relatos, 4, Ahi y ahora, Madrid, Alianza, 2004.

- «Cristal con una rosa dentro», en: Último round, Barcelona, Destino, 2005.

DELEUZE, Gilles: La lógica del sentido, Barcelona, Paidós, 2005.

DE MARTINO, Ernesto: Prefacio a Lucien Lévy-Bruhl, «La participación mágica», en Ernesto de Martino (Ed.), Magia y civilización, Buenos Aires, El Ateneo, 1965.

DERRIDA, Jacques: «Cogito e historia de la locura», en La escritura y la diferencia, Barcelona, Anthropos, 1989.

DOLEŽEL, Lubomír: Heterocosmica. Ficción y mundos posibles, Madrid, Arco/Libros, 1999.

ECO, Umberto: Lector in fabula. La cooperación interpretativa en los textos narrativos, Barcelona, Lumen, 1999.

-Los límites de la interpretación, Barcelona, Lumen, 2000.

FOUCAULT, Michel: Historia de la locura en la época clásica, México, Fondo de Cultura Económica, 1991.

-El pensamiento del afuera, Valencia, Pre-textos, 1988.

FREUD, Sigmund: La interpretación de los sueños, en Obras completas, Vol. I, Barcelona, Biblioteca Nueva, 2006.

-El inconsciente, en Obras completas, Vol. III, Barcelona, Biblioteca Nueva, $2006 \mathrm{a}$.

-Totem y tabu, en Obras completas, Vol. III, Barcelona, Biblioteca Nueva, $2006 \mathrm{~b}$.

- Lo siniestro, en Obras completas, Vol. IV, Barcelona, Biblioteca Nueva, 2006c.

HORN, Holloway: «Los ganadores de mañana», en Jorge Luis Borges, Adolfo Bioy Casares, Silvina Ocampo (Eds.), La antología de la literatura fantástica, Barcelona, Edhasa, 1981.

LUGNANI, Lucio: «Per una delimitazione del "genere"», en Remo Ceserani et al., La narrazione fantastica, Pisa, Nistri-Lischi, 1983.

MATTE BLANCO, Ignacio: Thinking, Feeling and Being. Clinical Reflections on the Fundamental Antinomy of Human Beings and World, trad. it. Pensare, sentire, essere. Riflessioni cliniche sull'antinomia fondamentale dell'uomo e del mondo, Pietro Bria (Ed.), Torino, Einaudi, 1995.

-The Unconscious as Infinite Sets. An Essay in Bi-logic, trad. it. L'inconscio come insiemi infiniti. Saggio sulla bi-logica, Pietro Bria (Ed.), Torino, Einaudi, 2000 . 
— «Riflessioni sulla creazione artistica» y «Note sulla creazione artistica», en Estetica ed infinito. Scritti di Ignacio Matte Blanco, Daniele Dottorini (Ed.), Roma, Bulzoni, 2000a.

- "Creatività ed ortodossia», en La bi-logica fra mito e letteratura. Saggi sul pensiero di Ignacio Matte Blanco, Pietro Bria y Fiorangela Oneroso (Eds.), Milano, FrancoAngeli, 2004.

MORENO SERRANO, Fernando Ángel: Teoría de la literatura de ciencia ficción. Poética y retórica de lo prospectivo, Vitoria, Portal, 2010.

PAVEL, Thomas: Mundos de ficción, Caracas, Monte Ávila Editores, 1994.

PREGO GADEA, Omar: La fascinación de las palabras, Buenos Aires, Alfaguara, 1997.

TERRAMORSI, Bernard: Le fantastique dans les nouvelles de Julio Cortázar: rites, jeux et passages, Paris, L'Harmattan, 1994. 